\title{
World-First Innovations in an Open Innovation Context
}

\author{
Franciane Paz Hochleitner ${ }^{1}$, Anna Arbussà ${ }^{2}$, Germà Coenders ${ }^{1 *}$
}

\begin{abstract}
This study contributes to the current literature on open innovation by analysing the effects of open innovation activities on the introduction of new-to-the-world innovations versus imitation. We base our analysis on data provided by the Eurostat Community Innovation Survey (CIS) carried out in Germany in 2012, which for the first time made a distinction between world-first innovation and imitation. We use both logit models and CHAID trees. The results of both analyses show that traditional in-house innovation and patents continue to make the largest contribution to world-first innovation in the so-called open-innovation era, while some specific open innovation activities contribute to a lesser extent: cooperation with customers, information from universities, cooperation with suppliers, and acquisition of machinery. Thus, promoting open innovation can be advantageous not only for imitative innovation but also for introducing world-first innovations. The European Commission should continue to include open innovation policies in its agenda.
\end{abstract}

Keywords: open innovation; world-first innovation; invention; imitation; appropriation instruments

Submitted: May 5th 2016/ Approved: September 11th 2016

\section{Introduction}

The Open Innovation paradigm is characterized by an increased and faster flow of information between firms (Dahlander \& Gann, 2010). More than a decade after the term 'open innovation' was coined by Chesbrough (2003) we believe that it is fitting to analyse whether this flow of information is beneficial for both product innovators (in the sense of inventors or world-first innovators) and imitators or is detrimental to either of them, and to analyse whether the rules of the game in this arena (such as the role of the sector, the size of the company and the use of appropriation instruments) remain the same or have changed. By product innovation, we refer to both innovative goods and services.

In 2010 and 2012 changes were made to the EUROSTAT Community Innovation Survey (CIS) - the microdata for which were simultaneously released in late 2015 - that made specific data about worldfirst innovation available for the first time. The new CIS classification concurs with the directives of the Oslo Manual; 'new to the firm' is the minimum degree of novelty of the innovation and refers to introducing products that are new for the firm but not for the market; 'new to the market' refers to being the first firm to launch the new product in its market; and 'new to the world' is the maximum grade of novelty, namely being the first to introduce the innovation in any market.

In general, world-first innovations can bring product innovator firms competitive advantages as they allow them to get a head start on their rivals and influence consumer preferences as well as gain the benefits of the protection and concession of patents. However, existing products provide imitator firms with the information needed to develop them, improve them and thus compete more effectively (Lieberman
\& Asaba, 2006). In addition, the costs of imitation are often much lower than the costs of innovation as an imitator company does not have to spend so much of its resources on R\&D (Zachary et al., 2015). Open innovation could affect the balance between innovation versus imitation and their relative advantages and disadvantages by easing the flow of information.

If considered in the Schumpeterian framework, open innovation could contribute to diminished incentives to invent through easing imitation and thus lowering the rents from inventions. However, from other perspectives, imitation (or more competitive markets) may also serve as a spur to innovation, with firms who do not innovate finding themselves penalized (Aghion et al., 1997). In some settings, where innovation is both sequential and complementary, the inventor firm might even be better off from having other firms imitating and competing against it (Bessen \& Maskin, 2009). Imitation can thus stimulate rather than dampen innovation under certain market competition conditions. In this regard, the fact that open innovation could encourage imitation through an increased flow of information and knowledge between firms (Dahlander \& Gann, 2010) does not mean that it would necessarily have negative effects on innovation (West et al., 2006).

The results of this study may be relevant for EU innovation policy design. Indeed, the European Commission's interest in open innovation has led to their commissioning various studies (European Commission, 2014) and funding different projects that aim to encourage open innovation (see the Horizon 2020 projects). The Commission has also included open innovation in some of their initiatives to promote innovation (see, for example, the Open Innovation Strategy and Policy Group's [OISPG] recent initiatives).

(1) Department of Economics, University of Girona, Girona, Spain.

(2) Department of Business Administration, Management and Product Design. University of Girona, Girona, Spain.

*Corresponding author: germa.coenders@udg.edu. 
Similarly, the results of this paper may also be relevant for managers as they shed light on the effects of particular open innovation activities and instruments that they may include in their firms' innovation or imitation strategies.

This article aims to use the 2012 CIS data from Germany to study the relationship between launching innovative goods or services that are new to the world, carrying out open and traditional innovation activities, and using appropriation instruments. The structure is as follows: it first briefly reviews the theoretical and empirical literature on open innovation and on the introduction of innovations as opposed to imitation; it then presents the data and methodology used and the results with two alternative analysis methods. Finally, it draws conclusions and comments upon limitations and future lines of research.

\section{Review of the literature}

In this review, we concentrate on three issues. The first is the classifications of the various degrees of product innovation, the second is the relationship between open innovation activities and innovation versus imitation, and the third is the relationship between appropriation instruments and innovation versus imitation.

By definition, all innovations must have some degree of novelty. According to the Oslo Manual, there are three degrees of novelty, 'new to the firm', 'new to the market' and 'new to the world'. 'New to the firm' is the minimum grade of novelty, 'new to the market' refers to the innovations that the enterprise is first to launch in its market and 'new to the world' is the maximum grade of novelty.

This classification corresponds to the most recent CIS data. CIS editions before 2010, however, only distinguished between innovations that were 'new to the firm' and the rest. The fact that CIS data is widely available across Europe means that there was much literature based on this reduced version of the concept of imitation versus innovation (Barge-Gil, 2010; Laursen \& Salter, 2006; Spithoven et al., 2013). To the best of our knowledge, only Amara and Landry (2005) and Hanel (2008) have modelled world-first innovation from innovation activities, and used Canadian data that was collected before the term open innovation was coined.

Taking advantage from the richer recently released CIS data, in this article we opt for the Oslo Manual definition of 'world-first innovations' and use a variable indicating whether any of the product or service innovations by the company between 2010 and 2012 were world-firsts or if they were all at most new to the market. Therefore, the so-called imitators in this paper could have been the first to launch products in their respective markets, but without their being world-firsts.

Imitation and innovation as defined above cannot be understood nowadays without taking into account the trend towards being more open. Since the term open innovation was first used by Chesbrough (2003), different theoretical and empirical studies have evaluated this change in the innovation paradigm (Dahlander \& Gann, 2010;
Giannopoulou et al., 2010; Huizingh, 2011; Laursen \& Salter, 2006; Van de Vrande et al., 2009; Wikhamn \& Wikhamn, 2013). The ease in the flow of information that characterizes open innovation may have had an effect on both the costs and benefits that innovation has for both inventors (world-first innovators) and imitators. On the one hand, many studies sustain that openness helps companies to optimise available resources and share the costs of innovation with other collaborators, in addition to facilitating the acquisition of the means to develop new technologies (Huizingh, 2011; Van de Vrande et al., 2009). On the other hand, some studies conclude that this increased circulation of knowledge can make retaining the value difficult for the innovator firm, especially when the innovation cannot be protected thus facilitating imitation (Laursen \& Salter, 2014).

Open innovation activities are classified as inbound (those that use external sources to drive and develop innovation) and outbound (processes by which firms reveal information or sell their technology). We focus on inbound innovation in this section (evidence of validity of inbound activities as measurement of openness can be found in Hochleitner et al., in press), while taking into consideration the fact that some appropriation instruments can also be used as outbound open innovation activities (see below).

Some studies sustain that inbound open innovation helps firms to improve their innovation performance through cooperation, and through exchanging and acquiring knowledge that comes from other external sources such as clients, suppliers, universities, technological centres, and competitors (Chesbrough, 2003; Dahlander \& Gann, 2010; Huizingh, 2011; Van de Vrande et al., 2009; Temel et al., 2013). This practice allows them to create synergies and to increase their chances of success in innovation projects (Lichtenthaler \& Lichtenthaler, 2009).

Inbound open innovation can even include other concepts that are closely related from the field of innovation management such as absorptive capacity, defined by Cohen and Levinthal (1990) as a firm's ability to evaluate, assimilate and apply knowledge that comes from external sources (Lichtenthaler \& Lichtenthaler, 2009). From this perspective, Cohen and Levinthal (1990, p. 131) sustain that absorptive capacity is driven by two interrelated ideas: 'Learning is cumulative and learning performance is greatest when the object of learning is related to what is already known'. Absorptive capacity can thus be built by engaging in in-house R\&D activities and can occur as a side effect (Cohen \& Levinthal, 1990).

Absorptive capacity in the context of open innovation has gained in importance in the literature (Dahlander \& Gann, 2010; Lichtenthaler \& Lichtenthaler, 2009), mainly because open innovation is one of the principal means by which firms can absorb external knowledge. Furthermore, it can generate advantages for both imitating and innovating, and it allows benefits from possible spillovers to be obtained (Dahlander \& Gann, 2010).

On the other hand, imitating can be more economical than innovating (Lieberman \& Asaba, 2006; Zachary et al., 2015), although 
this optimistic view of costs is not unanimous. Keupp \& Gassmann (2009) sustain that the transaction costs of using external sources of knowledge and intellectual property are factors that can negatively affect the appeal of imitating. Finally, a new consensus is being formed around the idea that imitation and innovation are not opposites but can, in fact, reinforce each other and coexist (Bessen \& Mankin, 2009).

Drawing from all the above-mentioned points, we formulate the following hypothesis:

H1. Inbound open innovation activities increase the likelihood of introducing world-first product innovations

As regards appropriation instruments, the traditional use was to protect inventions from being imitated by rivals (Levin et al., 1987). The literature on the protection of innovations places appropriation activities into two major categories: legal and strategic. Legal instruments involve formal registration: patents, trademarks and copyrights are included in this group. Strategic instruments are the rest of the actions taken by the company to impede or make the copy and appropriation of innovation rents more difficult. The complexity of products, leadtime advantage and secrecy are in this group (Arundel, 2001).

Many studies sustain that the effectiveness of appropriation instruments and the relative importance of each instrument vary significantly between industries and depend on the size of the company (Arundel, 2001; Levin et al., 1987). Arundel (2001) upholds that the category and number of appropriation instruments used by a firm to protect inventions can also vary according to what phase the innovation is in; that is, the company can make use of secrecy initially and then patent later.

In this regard, it must be pointed out that the use of patents and secrecy (commercial or industrial) has been widely studied both in the theoretical (see Hall et al., 2014 for a review) and the empirical literature (e.g. Arundel, 2001; Levin et al, 1987). There are also numerous studies that consider other appropriation instruments to protect innovations such as, most notably, confidentiality agreements, copyrights and trademarks, among others (e.g. Amara et al., 2008).

Levin et al. (1987) show that some of the strategic protection mechanisms, such as lead-time advantage and secrecy, are among the most effective instruments to protect a firm's innovations. Arundel (2001) provided quite similar results, indicating that firms usually opt for secrecy rather than for patents to protect their inventions, mainly because they prefer not to reveal valuable information to their competitors, especially in potentially profitable areas of research. Additionally, secrecy does not have to comply with the requirements demanded by the law of patents, which allows the firm to protect more of their valuable assets. However, secrecy does not detract from the fact that patents are better instruments for safeguarding the innovation, especially when it is relatively easy for competitors to imitate (Arundel, 2001).
In conclusion, it must be pointed out that such findings refer to protecting and safeguarding innovations that have been produced in a traditional innovation context based on technology and knowledge within the firm (Chesbrough, 2003). The author, however, sustains that companies can also benefit from outbound open innovation (processes by which companies reveal information or sell their technology).

While traditional innovation has considered appropriation instruments to be a way to protect innovations from imitation, open innovation considers them to be a way of selectively revealing knowledge and capturing the knowledge rents produced without having to introduce it to the market themselves. Dahlander and Gann (2010, p. 704) conceptualize these practices: selling 'refers to how firms commercialize their inventions and technologies through selling or licensing out resources developed in other organizations' and revealing 'refers to how firms reveal internal resources without immediate financial rewards, seeking indirect benefits'. If we link this to patents and secrecy, selling usually involves employing some sort of patent, while revealing involves failing to employ secrecy, at least partially.

Another line of the literature (e.g. Bessen \& Maskin, 2009) suggests that firms adopt strategies to selectively reveal some of their technologies to the public in order to elicit collaboration, but without any contractual guarantees of obtaining it. According to Dahlander and Gann (2010) being open and focusing less on ownership increases the opportunity to attract interest from other parties.

Thus, within the framework of open innovation, firms in a favourable business environment can make use of patents to take advantage of exploitation. In other words, patents can be positively related to world-first innovation even under the open innovation paradigm. While the widespread use of secrecy is opposed to the concept of open innovation by its very nature, it could continue to be used by world-first innovators with a traditional profile, or selectively within an open profile.

Drawing on the above, we formulate the following hypothesis:

H2. Some appropriation instruments, notably patents, increase the likelihood of introducing world-first product innovations.

\section{Data and variables}

The data used in this study come from the Eurostat Community Innovation Survey (CIS) carried out in Germany in 2012. We turn to the CIS because it follows the directives of the Oslo Manual and its data are standardised, trustworthy, comparable and taken from large samples that are representative of the country's economy as a whole and not only of the high technology sectors (Laursen \& Salter, 2006). Regarding the country, we opted for Germany because this economy is one of the leaders for innovation according to the Innovation Union Scoreboard. In the CIS 2012 microdata for this country, we find the 
highest frequency of firms with world-first innovation, both in absolute terms and in the percentage of the total sample (8.2\%). Statistical models predicting qualitative behaviours lose statistical power when the behaviour under study is only observed in a small number of cases. Therefore, the German market is the best option to see whether traditional innovation practices or open innovation practices contribute most to the introduction of new products onto the world market.

The sample includes firms with 10 or more employees which represent all sectors of the manufacturing and service industries. Of those surveyed, only enterprises that declared they had innovated goods or services were taken into account. In accordance with this filter, once the cases with missing values were excluded, we identified 1,715 firms who, during the period 2010-2012, declared that they had carried out at least one innovation related to goods/services, of which 406 (23.7\%) affirmed that at least some of their innovations could be classified as world-firsts.

The variables we considered are (Table 1):

1. Dependent variable. The dependent variable indicates the presence of world-first goods or services. The CIS 2012 question 'To the best of your knowledge, were any of your product innovations during the three years 2010 to 2012 a world-first?' (referring to a previous question about new or significantly improved goods and services introduced during the same period) was used. 'yes' was coded as 1 and 'no' as 0.

2. Explanatory variables. As explanatory we used the range of appropriation instruments available in the CIS for the analysis: (i) patents, (ii) trademarks and copyrights, (iii) complexity of products and (iv) secrecy. On the one hand, we used the two typical variables of innovation activities: (1) in-house R\&D and (2) information sources from within the enterprise; and, on the other hand, inbound open innovation activities: (3) cooperation with suppliers, (4) cooperation with customers (5) cooperation with competitors, (6) information sources from consultants, (7) information sources from universities and government, (8) external R\&D, (9) acquisition of machinery, equipment and software and (10) acquisition of knowledge. The CIS contained a longer list of variables of cooperation, information and appropriation instruments. We decided on the definitive list of 14 variables by carrying out a collinearity analysis. For example, information from universities and cooperation with universities were highly correlated, as were information from competitors and collaboration with competitors; so, in each case, the variable that made more theoretical sense was chosen. Van de Vrande et al. (2009), for example, suggest that obtaining information from customers is within the possibilities of any organization, including those that practice traditional innovation, while on the other hand, cooperating with customers is a clearer indicator of openness (Barge-Gil, 2010). We converted all of the variables into binaries. The variables In-House R\&D, External R\&D, acquisition of machinery and acquisition of external knowledge were already binary in the CIS (1='yes', $0=$ 'no'). For the information sources and appropriation instruments, the categories 'not used' and 'low' were grouped together (0) and the categories 'medium' and 'high' were grouped together (1). For the cooperation variables the category 'yes' (1) included any cooperation regardless of geographical location. A similar approach was followed by Hochleitner et al. (in press).

3. Control variables. As controls, we included the size of the company, measured by the number of employees (following the directives of the Oslo Manual, 2005). We classified the companies into three different groups: large firms, SMEs belonging to a group and independent SMEs (reference category). We also included industry, which we grouped into 9 major categories following the NACE classification. Other services act as a reference category. 
Table 1. Frequencies of independent variables and imitators and world-first innovators

\begin{tabular}{|c|c|c|c|c|}
\hline & & $\%$ Within Imitators & $\begin{array}{l}\% \text { Within world- } \\
\text { first Innovators }\end{array}$ & $\%$ Total \\
\hline \multicolumn{5}{|l|}{ Innovation activities } \\
\hline \multirow{2}{*}{ In-house R\&D } & NO & 35.3 & 6.4 & 28.5 \\
\hline & YES & 64.7 & 93.6 & 71.5 \\
\hline \multirow{2}{*}{ Inf. sources from within the enterprise } & NO/LOW & 12.6 & 6.7 & 11.2 \\
\hline & MED/HIGH & 87.4 & 93.3 & 88.8 \\
\hline \multirow{2}{*}{ Cooperation with suppliers } & NO & 87.2 & 74.4 & 84.1 \\
\hline & YES & 12.8 & 25.6 & 15.9 \\
\hline \multirow{2}{*}{ Cooperation with customers } & NO & 84.3 & 71.2 & 81.2 \\
\hline & YES & 15.7 & 28.8 & 18.8 \\
\hline \multirow{2}{*}{ Cooperation with competitors } & NO & 92.7 & 87.4 & 91.5 \\
\hline & YES & 7.3 & 12.6 & 8.5 \\
\hline \multirow{2}{*}{ Inf. sources from consultants } & NO/LOW & 77.2 & 84.7 & 79.0 \\
\hline & MED/HIGH & 22.8 & 15.3 & 21.0 \\
\hline \multirow{2}{*}{ Inf. sources from universities and government } & NO/LOW & 68.0 & 49.5 & 63.6 \\
\hline & MED/HIGH & 32.0 & 50.5 & 36.4 \\
\hline \multirow{2}{*}{ External R\&D } & NO & 69.6 & 48.0 & 64.5 \\
\hline & YES & 30.4 & 52.0 & 35.5 \\
\hline \multirow{2}{*}{ Acquisition of machinery, equipment and software } & NO & 28.7 & 20.0 & 26.6 \\
\hline & YES & 71.3 & 80.0 & 73.4 \\
\hline \multirow{2}{*}{ Acquisition of knowledge } & NO & 70.6 & 64.3 & 69.1 \\
\hline & YES & 29.4 & 35.7 & 30.9 \\
\hline \multicolumn{5}{|l|}{ Appropriation instruments } \\
\hline \multirow{2}{*}{ Patents } & NO/LOW & 59.1 & 29.3 & 52.0 \\
\hline & MED/HIGH & 40.9 & 70.7 & 48.0 \\
\hline \multirow{2}{*}{ Trademarks and Copyright } & NO/LOW & 48.4 & 34.5 & 45.1 \\
\hline & MED/HIGH & 51.6 & 65.5 & 54.9 \\
\hline \multirow{2}{*}{ Complexity of goods or services } & NO/LOW & 37.4 & 27.3 & 35.0 \\
\hline & MED/HIGH & 62.6 & 72.7 & 65.0 \\
\hline \multirow{2}{*}{ Secrecy } & NO/LOW & 43.7 & 30.8 & 40.6 \\
\hline & MED/HIGH & 56.3 & 69.2 & 59.4 \\
\hline \multicolumn{5}{|l|}{ Size } \\
\hline \multicolumn{2}{|l|}{ Large enterprise } & 17.6 & 34.2 & 21.6 \\
\hline \multicolumn{2}{|l|}{ SME in an enterprise group } & 22.8 & 22.2 & 22.7 \\
\hline \multicolumn{2}{|l|}{ Independent SME } & 59.5 & 43.6 & 55.7 \\
\hline \multicolumn{5}{|l|}{ Nace } \\
\hline \multicolumn{2}{|l|}{ Food, mining, construction } & 10.7 & 5.2 & 9.4 \\
\hline \multicolumn{2}{|l|}{ Textile, fur, wood, paper industries } & 10.4 & 13.8 & 11.2 \\
\hline \multicolumn{2}{|l|}{ Publishing printing and recorded media industries } & 5.7 & 6.9 & 5.9 \\
\hline Rubber and plastic manufacturing & & 6.4 & 7.9 & 6.8 \\
\hline Metal manufacturing & & 17.3 & 38.9 & 22.4 \\
\hline Machinery and equipment manufacturing & & 3.5 & 5.4 & 4.0 \\
\hline Other manufactures & & 9.5 & 6.9 & 8.9 \\
\hline Retailing, repair and transport & & 16.3 & 7.4 & 14.2 \\
\hline Other services & & 20.2 & 7.6 & 17.2 \\
\hline
\end{tabular}




\section{Statistical analysis}

The relationship between introducing or not world-first good and service innovations, the activities, the appropriation instruments and the controls are specified as a binary logistic regression model (Hosmer \& Lemeshow, 2004) as:

$y_{i}^{*}=\mathbf{x}_{\mathbf{i}} \beta+u_{i}$,

where $y_{i}^{*}$ is an underlying continuous dependent variable, which is not observed. The categorized $y_{i}$ variable with two categories is observed instead as $y_{i}=0$ if $y_{i}^{*} \varsigma \tau$ (imitators) and $y_{i}=1$ (world-first innovators) if $y_{i}^{*}>\tau y_{i}^{*}$ thus shows the propensity to introduce world-first innovations. $\mathbf{x}_{\mathrm{i}}$ is a row vector of explanatory variables, which in our case includes dummy coded innovation activities and appropriation instruments as well as dummy coded controls. $u_{i}$ stands for the coefficient vector. $u_{i}$ is a disturbance term with a logistic distribution with null location parameter and unit scale parameter. The exponential transformation of the coefficients can be interpreted as odd-ratios.
Groups of firms with combinations of activities, appropriation instruments or control characteristics leading to a particularly high proportion of world-first product innovations were identified by means of using the Chi-Squared Automatic Interaction Detector technique (CHAID), a particular case of decision and regression tree (Magidson, 1994). The maximum depth of the tree was specified as 4 with a minimum terminal node size of 50 firms and alpha risk equal to 0.05 applying Bonferroni's inequality to prevent the accumulation of risks due to multiple testing.

\section{Modelling world-first innovation from innovation activities and appropriation instruments}

As regards the application of the logit model, according to Table 2, the Nagelkerke's R-squared of the relationship between innovation activities, appropriation instruments, controls and world-first product innovation is 0.261 .

Table 2. The relationship between innovation activities and appropriation instruments and world-first product innovation.

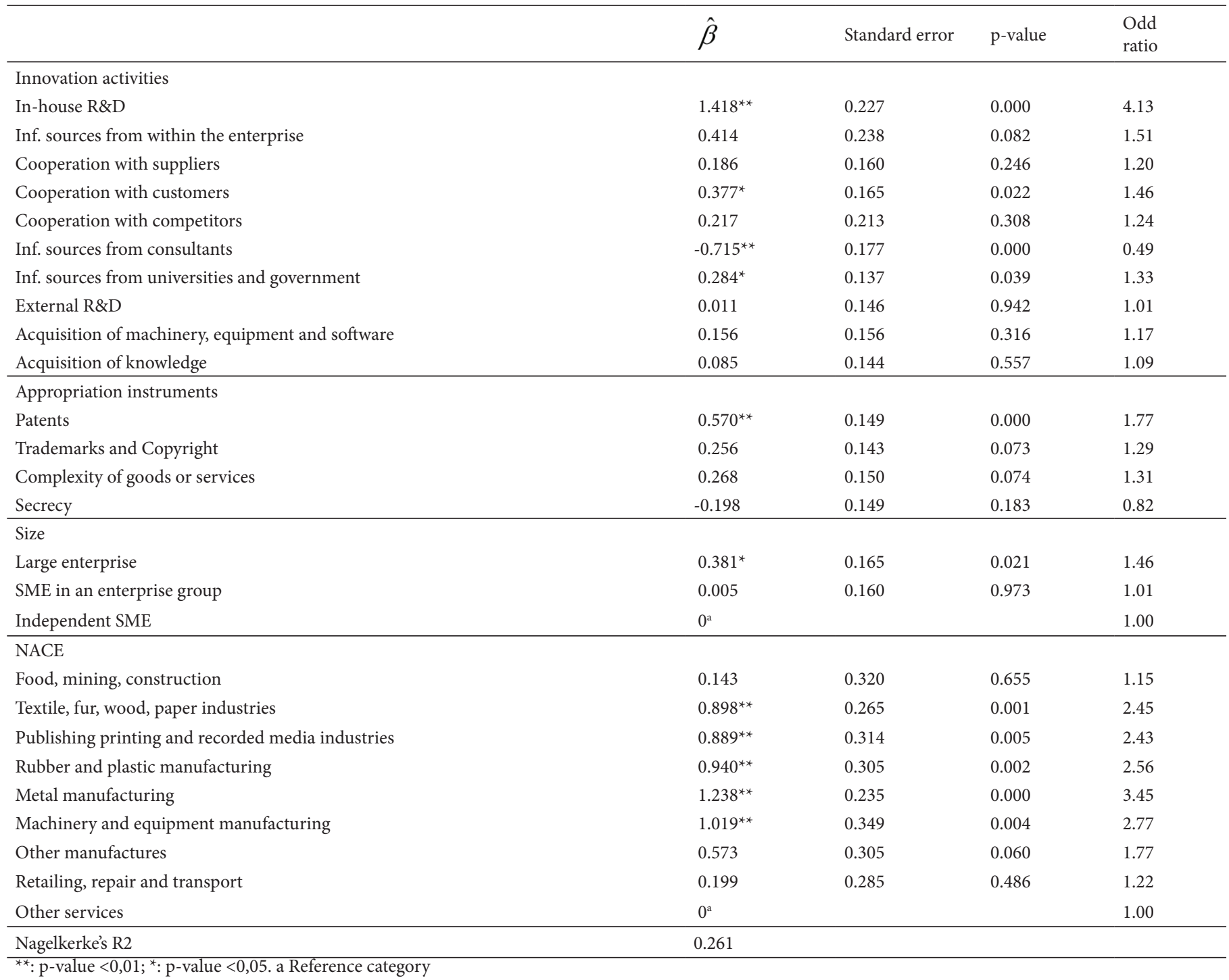


The results show that in-house $\operatorname{R} \& \mathrm{D}(\hat{\beta}=1.418$; $\mathrm{p}<.01$; odd-ratio $=4.13)$, the traditional innovation activity, has the greatest positive effect on the launch of world-first goods and services. The use of internal sources of information, on the other hand, does not have a significant effect. According to the percentages in Table 1 this activity can be taken for granted in most firms $(88.8 \%)$.

However, it must be highlighted that some of the inbound open innovation activities have a positive effect on launching new-to-the-world goods and services. This is the case for cooperation with customers ( $\hat{\beta}=.377 ; \mathrm{p}<.05$; odd-ratio=1.46) and information sources from universities and the government $(\hat{\beta}=.284 ; \mathrm{p}<.05$; odd-ratio=1.33). This result partially confirms hypothesis 1 . On the other hand, the use of information sources from consultants has a negative effect on worldfirst products ( $\hat{\beta}=-.715 ; \mathrm{p}<.01$; odd-ratio $=0.49$ ). This could be attributed to the level of consolidation of the information that is usually transmitted by consultation, which is often not the type of leadingedge knowledge that is needed for world-first innovation. The other open innovation activities have no significant effect on world-first products.

Patents are the only appropriation instruments to exercise a significant positive effect on world-first products $(\hat{\beta}=.570 ; \mathrm{p}<.01$; oddratio=1.77). No instruments have a significant negative effect. This result partially confirms hypothesis 2 .

With respect to the control variables, large firms are the only ones that stand out from both independent SMEs and those that belong to a group, and they are also the ones that are more likely to introduce world-first products. With regards to NACE, metal manufacturing has the highest likelihood of introducing world-first products, closely followed by machinery/equipment manufacturing, rubber/plastic manufacturing, textile/fur/wood/paper manufacturing and the publishing, printing and recorded media industries. The other manufacturing industries are somewhere in the middle, and the primary sector, construction, and services are at the bottom.

\section{Combinations of firm characteristics, appropriation instruments and activities leading to world-first innovation}

Regarding the application of the CHAID method (Figure 1), the following variables contribute to identifying groups of firms with varying degrees of success in introducing world-first innovations. The first variable is in-house $\mathrm{R} \& \mathrm{D}$, which appears to be a necessary condition for success in new-to-the-world innovation (only $5.3 \%$ of firms without in-house R\&D achieve world-firsts). For the sake of brevity, from here on we will only comment on combinations of characteristics with particularly high world-first innovation rates.

Among firms with in-house R\&D activities, a medium or high use of patents contributes most to increasing the world-first innovation rate. The sample includes $40.2 \%$ of cases with both in-house R\&D and patents, with a rate of world-first innovations of $39.8 \%$.

Among firms with in-house R\&D activities and patents, being a large enterprise contributes to increasing the world-first innovation rate. The group that combines these three characteristics includes $14.1 \%$ of sample cases, with a rate of world-first innovations of 52.5\%. Among large firms with in-house R\&D activities and patents, cooperation with suppliers contributes to further increasing the world-first innovation rate. $4.8 \%$ of firms combine these four characteristics, and this subgroup has a world-first innovation rate of $65.1 \%$.

In the case of SMEs (both independent SMEs and those belonging to a group), combining in-house $\mathrm{R} \& \mathrm{D}$ and patents, the acquisition of machinery, equipment and software contributes to increasing the world-first innovation rate. $19.4 \%$ of firms combine these four characteristics, with a world-first innovation rate of $37.3 \%$.

In the case of firms with in-house R\&D activities that do not use patents, belonging to manufacturing industries contributes to increasing the world-first innovation rate. The node includes $14 \%$ of sample cases, with a rate of world-first innovations of $29.2 \%$. Among firms with in-house $R \& D$ activities that do not use patents and belong to manufacturing industries, trademarks and copyright contribute to increasing the world-first innovation rate. This combination of characteristics includes $5.4 \%$ of cases, with a rate of world-first innovations of $37 \%$.

Figure 1. CHAID tree of world-first product innovators

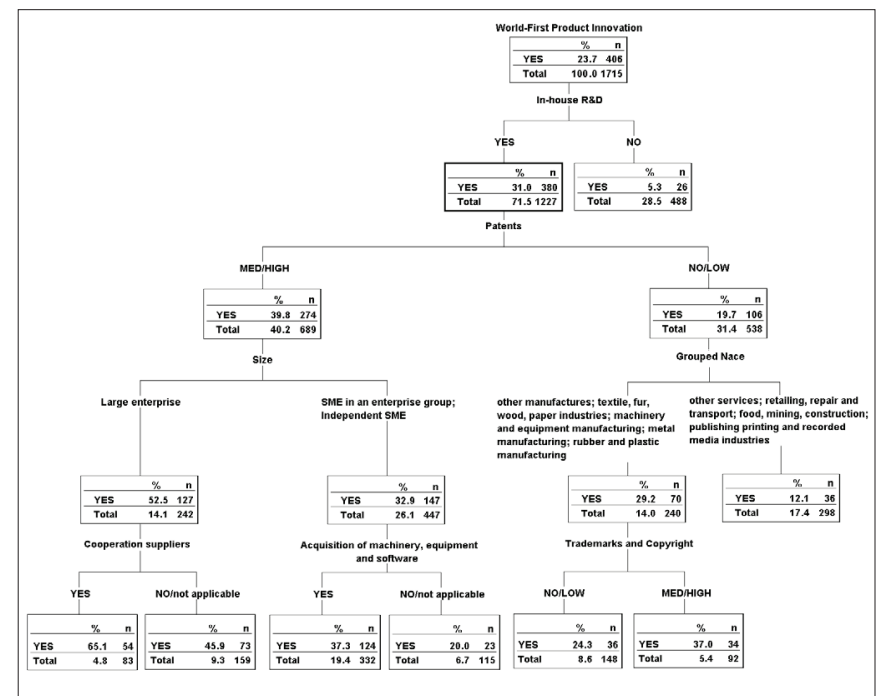

Discussion

The results of this study provide significant evidence that above all German companies continue to use activities and appropriation instruments from traditional innovation to introduce good and service innovations to the world.

The logit model and the CHAID technique provide complementary and convergent insights. In both cases, in-house $\mathrm{R} \& \mathrm{D}$ and patents are the main variables related to world-first innovators. Furthermore, in both techniques, all of the inbound and the remaining outbound open innovation activities appear to have no adverse effects on 
world-first innovations. The only exception is consultants. Certain inbound open innovation activities do have a favourable effect on world-first innovation; they appear with moderate significant coefficients in the logit model and at the bottom of the CHAID tree.

These results can be classified as typical in the sense that the activities that characterise innovations at a world level are internal R\&D and the use of patents, coinciding with the results that studies on innovation carried out previous to the open innovation context tended to give (e.g. Amara \& Landry, 2005; Hanel, 2008). This statement does not undermine the open innovation paradigm. This study shows that cooperation with customers, information from universities and the government, cooperation with suppliers and the acquisition of machinery play to the advantage of world-first innovators, at least in some cases. The only open innovation activity that is detrimental to world-first innovation is the use of information from consultants, as discussed above.

The refinement that discriminates between firms that launch innovations at a world level and those that launch innovations only at a market or firm level sheds light on the distinction between the creation and the imitation of innovations. This distinction is relevant because it coincides with the classification that has been established in a large part of the theoretical literature (Lieberman \& Asaba, 2006; Zachary et al., 2015), while the empirical literature has tended to consider innovation at a market level to be sufficient, at least in the European context (Barge-Gil, 2010; Laursen \& Salter, 2006). This distinction is important, for example, when considering the effects of innovation on the growth of an economy and, consequently, when shaping policies to encourage innovation (European Commission, 2014). The results of this study show that promoting open innovation can be advantageous for the introduction of world-first innovations, thus lending support to initiatives like Open Innovation 2.0, which is included in the Digital Agenda for Europe.

\section{Conclusions}

The aim of this article is to study the relationship that open innovation activities and appropriation instruments have with the introduction of new-to-the-world innovations. To this end, we use the data of the CIS 2012 carried out in Germany. The statistical analysis produces several significant results. First, beyond the still decisive role of traditional innovation, our results show that some inbound open innovation activities have a positive effect on world-first product innovation. Second, amongst the appropriation instruments, only patents exercise a significant positive effect on world-first product innovation.

As regards the main implications and contributions of this study, besides helping to determine the appropriateness of policies supporting open innovation as mentioned above, our results are relevant for practising managers as they assist them in identifying which open innovation practices might be more productive. For instance, we show that when it comes to world-first innovation, large enterprises may find greater benefit from cooperating with suppliers and SMEs from acquiring machinery.
Several limitations of this study need to be noted. First, the data used are based on German firms and therefore the results are specific to that country. The effects of open innovation activities and appropriation instruments on world-first innovation from other countries could be significantly different. Future research is required to verify whether these results can be applied elsewhere. Second, our results are specific to the innovation of goods and services and do not include other types, such as the innovation of processes. Despite the fact this study considers a wide range of innovation activities in the analysis, the CIS information is limited regarding outbound open innovation. Appropriation instruments may or may not be used for outbound open innovation purposes. This limitation is related to the use of official statistics data, whose range of variables is not controlled by the researcher. Last, the broad definition of innovation used by the OCDE - 'Did your firm offer new or significantly improved products (goods or services)?' - has advantages over a narrower vision - R\&D spending and obtaining patents - but on the other hand it runs the risk of counting relatively minor improvements to goods or services as innovations at a world level. In any case, the results obtained from this study, where in-house R\&D and patents stand out when explaining the originality of the innovations, could be an indicator of convergent validity. Further research on world-first innovation in an open innovation context is required, using data from diverse sources.

\section{Acknowledgements}

Acknowledgements are due to Eurostat for providing us with the Community Innovation Survey microdata. Authors have all responsibility for the results obtained. The first author was supported by the University of Girona grant (BR-UdG). The second author was supported by the Spanish Ministry of Economy and Competitiveness grant ECO2013-46954-C3-3-R, by the Catalan Autonomous Government grant 2014SGR868, and by the University of Girona grant MPCUdG2016/093. The third author was supported by the Catalan Autonomous Government grant 2014SGR551, by the Spanish Health Ministry grant CB06/02/1002, by the Spanish Economy and Competitiveness Ministry grant MTM2015-65016-C2-1-R, and by the University of Girona grant MPCUdG2016/069.

\section{References}

Aghion, P., Harris, C., \& Vickers, J. (1997). Competition and growth with step-by-step innovation: An example. European Economic Review, 41, 771-782. http://dx.doi.org/10.1016/S0014-2921(97)00036-6

Amara, N., \& Landry, R. (2005). Sources of information as determinants of novelty of innovation in manufacturing firms: evidence from the 1999 statistics Canada innovation survey. Technovation, 25(3), 245-259. http://dx.doi.org/10.1016/S0166-4972(03)00113-5

Amara, N., Landry, R., \& Traoré, N. (2008). Managing the protection of innovations in knowledge-intensive business services. Research Policy, 37(9), 1530-1547. http://dx.doi.org/10.1016/j.respol.2008.07.001 
Arundel, A. (2001). The relative effectiveness of patents and secrecy for appropriation. Research Policy, 30(4), 611-624. http://dx.doi. org/10.1016/S0048-7333(00)00100-1

Barge-Gil, A. (2010). Cooperation-based innovators and peripheral cooperators: An empirical analysis of their characteristics and behaviour. Technovation, 30(3), 195-206. doi:10.1016/j.technovation.2009.11.004

Bessen, J., \& Maskin, E. (2009). Sequential innovation, patents and imitation. The Rand Journal of Economics, 40(4), 611-635. http:// dx.doi.org/10.1111/j.1756-2171.2009.00081.x

Chesbrough, H. (2003). Open innovation: The new imperative for creating and profiting from technology. Boston: Harvard Business School Press.

Cohen, W.M., \& Levinthal, D.A. (1990). Absorptive capacity: a new perspective on learning and innovation. Administrative Science Quarterly, 35(1), 128-152. http://dx.doi.org/10.2307/2393553

Dahlander, L., \& Gann, D.M. (2010). How open is innovation? Research Policy, 39(6), 699-709. http://dx.doi.org/10.1016/j.respol.2010.01.013

European Commission (2014). Boosting open innovation and knowledge transfer in the European Union. Luxembourg: European Union Publications Office.

Giannopoulou, E., Ystrom, A., Ollila, S., Fredberg, T., \& Elmquist, M. (2010). Implications of openness: a study into (all) the growing literature on open innovation. Journal of Technology Management \& Innovation, 5(3), 162-167. http://dx.doi.org/10.4067/S071827242010000300012

Hall, B., Helmers, C., Rogers, M., \& Sena, V. (2014). The choice between formal and informal intellectual property: a review. Journal of Economic Literature, 52(2), 375-423. http://dx.doi.org/10.1257/jel.52.2.375

Hanel, P. (2008). The use of intellectual property rights and innovation by manufacturing firms in Canada. Economics of Innovation and New Technology, 17(4), 285-309. http://dx.doi. org/10.1080/10438590701581481

Hochleitner, F.P., Arbussà, A., \& Coenders, G. (in press). Inbound open innovation in SMEs: indicators, non-financial outcomes and entry-timing. Technology Analysis \& Strategic Management. http:// dx.doi.org/10.1080/09537325.2016.1211264

Hosmer Jr, D.W., \& Lemeshow, S. (2004). Applied logistic regression. New York: Wiley.

Huizingh, E.K.R.E. (2011). Open innovation: state of the art and future perspectives. Technovation, 31(1), 2-9. http://dx.doi.org/10.1016/j. technovation.2010.10.002

Keupp, M.M., \& Gassmann, O. (2009). Determinants and archetype users of open innovation. R\&D Management, 39(4), 331-341. http:// dx.doi.org/10.1111/j.1467-9310.2009.00563.x
Laursen, K., \& Salter, A. (2006). Open for innovation: the role of openness in explaining innovation performance among UK manufacturing firms. Strategic Management Journal, 27(2), 131-150. http:// dx.doi.org/10.1002/smj.507

Laursen, K., \& Salter, A. (2014). The paradox of openness: appropriability, external search and collaboration. Research Policy, 43(5), 867878. http://dx.doi.org/10.1016/j.respol.2013.10.004

Levin, R., Kievorick, A., Nelson, R.R., \& Winter, S.G. (1987). Appropriating the returns from industrial research and development. Brookings Papers on Economic Activity, 3, 783-831. http://dx.doi. org/10.2307/2534454

Lichtenthaler, U., \& Lichtenthaler, E. (2009). A capability-based framework for open innovation: complementing absorptive capacity. Journal of Management Studies, 46(8), 1315-1338. http://dx.doi. org/10.1111/j.1467-6486.2009.00854.x

Lieberman, M.B., \& Asaba, S. (2006). Why do firms imitate each other?. Academy of Management Review, 31(2), 366-385. http:// dx.doi.org/10.5465/AMR.2006.20208686

Magidson, J. (1994). The chaid approach to segmentation modeling: Chisquared automatic interaction detection. In R.P. Bagozzi (Ed.), Advanced methods of marketing research (pp. 118-159). Cambridge, MA: Blackwell.

Spithoven, A., Vanhaverbeke, W., \& Roijakkers, N. (2013). Open innovation practices in SMEs and large enterprises. Small Business Economics, 41(3), 537-562. http://dx.doi.org/10.1007/s11187-012-9453-9

Temel, S., Mention, A.L., \& Torkkeli, M. (2013). The impact of cooperation on firms' innovation propensity in emerging economies. Journal of Technology Management \& Innovation, 8(1), 54-64. http:// dx.doi.org/10.4067/S0718-27242013000100006

Van de Vrande, V., De Jong, J.P., Vanhaverbeke, W., \& De Rochemont, M. (2009). Open innovation in SMEs: trends, motives and management challenges. Technovation, 29(6), 423-437. http://dx.doi. org/10.1016/j.technovation.2008.10.001

West, J., Vanhaverbeke, W., \& Chesbrough, H. (2006). Open innovation: a research agenda. In $\mathrm{H}$. Chesbrough, W. Vanhaverbeke \& J. West, (Eds.), Open innovation: Researching a new paradigm (pp. 285307). Oxford: Oxford University Press.

Wikhamn, B.R., \& Wikhamn, W. (2013). Structuring of the open innovation field. Journal of Technology Management \& Innovation, 8(3), 173-185. http://dx.doi.org/10.4067/S0718-27242013000400016

Zachary, M.A., Gianiodis, P.T., Payne, G.T., \& Markman, G.D. (2015). Entry-timing enduring lessons and future directions. Journal of Management, 41(5), 1388-1415. http://dx.doi. org/10.1177/0149206314563982 